\title{
Analysis on the Change in Neutronic Parameters Due to Mispositioning of Fuel in the AP1000 Core
}

\section{J. Susilo, I. Kuntoro, T.M. Sembiring}

Center for Nuclear Reactor Technology and Safety - BATAN, Kawasan PUSPIPTEK Gd. No.8o, Setu, Tangerang Selatan, 15310

\section{Abstract}

AP1000 on the first cycle operation uses three types of $\mathrm{UO}_{2}$ fuel enrichments that are 2.35 $\mathrm{W} / \mathrm{o}, 3.40 \mathrm{w} / 0$ and $4.50 \mathrm{w} / \mathrm{o}$. To compensate excess reactivity, AP1000 uses an Integrated Fuel Burnable Absorber (IFBA) and a PYREX absorber as additional compensator to the boric solution in the moderator. IFBA is a burnable absorber made from $\mathrm{ZrB}_{2}$ which is integrated into the $\mathrm{UO}_{2}$ fuel. Human errors, such as fuel misposition, could happen when operators load fuel assemblies into the reactor core. For evaluating the design performance of AP1000, analysis on the change of neutronic parameters due to this fuel mispositioning need to be done. Analysis was performed on the reactor at hot zero power condition (HZP), beginning of cycle (BOC), and zero xenon condition with several cases of mispositioning between two adjacent fuels. Neutronic parameters, mainly the k-eff and power factor distribution will

Corresponding Author:

J. Susilo,

email: shushilo@batan.go.id

Received: 29 July 2016 Accepted: 21 August 2016 Published: 21 September 2016

\section{Publishing services} provided by Knowledge E

(c) J. Susilo. et al. This article is distributed under the terms of the Creative Commons Attribution License, which permits unrestricted use and redistribution provided that the original author and source are credited.

Selection and Peer-review under the responsibility of the ICONETS Conference Committee.

\section{S OPEN ACCESS} be derived from SRAC2006 computer code module of CITATION. One of the inputs required is fuel lattice macroscopic cross-section data, which are generated by PIJ module. These calculations performed condensation energy group of 107 into 10 groups with JENDL - 3.3 library cross section data. From the analysis, it can be concluded that misposition of the fuel in the first cycle of AP1000 core will result in very small change to the neutronic parameters. This very small change cannot reduce the performance of the core.

\section{Keywords: Fuel mispositioning, neutronic parameter, AP10oo}

\section{Introduction}

AP1000 is a pressurized water reactor (PWR) that can produce a nominal power of 1154 MWe (3415 MWth). The reactor is designed by Westinghouse Co. based on the perfomance of the proven PWR. AP1000 reactor can be operated for 18 months for each cycle and has a life time of about 60 years. Today, AP1000 reactors are still under construction in several countries, such as Bulgaria, England, China, and U.S.A [1, 2].

In the frame of evaluation of the core safety system in National Nuclear Energy Agency (BATAN), a simulation calculation using computer code on safety design parameter of AP1000 core has been done. Some related researches that have been done are analysis on the criticality of AP1000 core [3], analysis on the coefficient reactivity of the $1000 \mathrm{MWe}$ PWR [4], kinetic parameter calculation of AP1000 core $[5,6]$, and analysis of using mixed oxide (MOX) fuel on AP1000 core design [7, 8, 9]. 
At the first operation cycle, AP1000 core uses 3 type enrichments of $\mathrm{UO}_{2}$ fuels, that are $2.35 \mathrm{w} / \mathrm{o}, 3.40 \mathrm{w} / \mathrm{o}$ and $4.50 \mathrm{w} / \mathrm{o}$. To compensate the effective multiplication factor $\left(k_{\text {eff }}\right)$ or excess reactivity in the beggining of cycle of the AP100o core, borid acid which is dissolved in moderator, Pyrex absorber rod and Integrated Fuel Burnable Absorber (IFBA) are used. IFBA is a burnable absorber made frome $\mathrm{ZrB}_{2}$ which is integrated into $\mathrm{UO}_{2}$ fuel, whereas Pyrex is an absorber rod made from $\mathrm{B}_{2} \mathrm{O}_{3}$ which is inserted into the guide tube $[10,11]$. In the core, $\mathrm{UO}_{2}$ fuel, IFBA and Pyrex are arranged to form a configuration in such away that it can generate the neutronic parameters which meet the safety criteria, so the core configuration is safe and feasible to be operated. Figure 1 shows distribution of fuel and Pyrex layout on the quarter core of the AP1000 according to the inial design.

\begin{tabular}{|c|c|c|c|c|c|c|c|}
\hline $\mathrm{H}$ & G & $F$ & $E$ & D & $C$ & B & A \\
\hline 2.35 & $\begin{array}{c}3.40 \\
881 \\
24 \mathrm{P}\end{array}$ & 2.35 & $\begin{array}{l}3.40 \\
881 \\
24 \mathrm{P}\end{array}$ & 2.35 & $\begin{array}{r}3.40 \\
281 \\
24 \mathrm{P}\end{array}$ & 2.35 & $\begin{array}{r}4.45 \\
881 \\
12 \mathrm{P} \\
\end{array}$ \\
\hline $\begin{array}{c}3.40 \\
881 \\
24 \mathrm{P}\end{array}$ & 2.35 & $\begin{array}{c}3.40 \\
881 \\
24 \mathrm{P}\end{array}$ & 2.35 & $\begin{array}{c}3.40 \\
881 \\
24 \mathrm{P}\end{array}$ & 2.35 & $\begin{array}{c}4.45 \\
721 \\
24 \mathrm{P}\end{array}$ & $\begin{array}{c}4.45 \\
881 \\
9 P\end{array}$ \\
\hline 2.35 & $\begin{array}{c}3.40 \\
881 \\
24 \mathrm{P}\end{array}$ & 2.35 & $\begin{array}{l}3.40 \\
881 \\
24 \mathrm{P}\end{array}$ & 2.35 & $\begin{array}{c}3.40 \\
28 \mathrm{I} \\
24 \mathrm{P}\end{array}$ & $\begin{array}{l}4.45 \\
1121\end{array}$ & \\
\hline $\begin{array}{c}3.40 \\
881 \\
24 \mathrm{P}\end{array}$ & 2.35 & $\begin{array}{c}3.40 \\
881 \\
24 \mathrm{P}\end{array}$ & 2.35 & $\begin{array}{c}3.40 \\
441 \\
24 \mathrm{P}\end{array}$ & $\begin{array}{l}4.45 \\
1121\end{array}$ & $\begin{array}{l}4.45 \\
1121\end{array}$ & \\
\hline 2.35 & $\begin{array}{c}3.40 \\
881 \\
24 \mathrm{P}\end{array}$ & 2.35 & $\begin{array}{c}3.40 \\
44 I \\
24 \mathrm{P}\end{array}$ & 2.35 & $\begin{array}{l}4.45 \\
1121\end{array}$ & & \\
\hline $\begin{array}{c}3.40 \\
28 I \\
23 \mathrm{P}\end{array}$ & 2.35 & $\begin{array}{c}3.40 \\
281 \\
24 \mathrm{P}\end{array}$ & $\begin{array}{l}4.45 \\
1121\end{array}$ & $\begin{array}{l}4.45 \\
1121\end{array}$ & & & \\
\hline 2.35 & $\begin{array}{l}4.45 \\
721 \\
24 \mathrm{P}\end{array}$ & $\begin{array}{l}4.45 \\
112 I\end{array}$ & $\begin{array}{l}4.45 \\
1121\end{array}$ & & & & \\
\hline $\begin{array}{c}4.45 \\
881 \\
12 P\end{array}$ & $\begin{array}{c}4.45 \\
881 \\
9 P\end{array}$ & & & & & & $\begin{array}{l}\text { w/o } \\
\text { IFBA } \\
\text { Pyrex }\end{array}$ \\
\hline
\end{tabular}

Figure 1: Fuel and Pyrex layout in a quarter core of the AP1000.

Part of $\mathrm{UO}_{2}$ pellets are coated with absorbent material $\mathrm{ZrB}_{2}$ (called with IFBA fuel) and the remaining are without absorbent material. Fuel assembly is composed by a $17 \times 17$ fuel arangement with a certain ratio between the number of $\mathrm{UO}_{2}$ to IFBA. Based on the $\mathrm{UO}_{2}$ enrichment and number of IFBA, there will be 9 different types of fuel assemblies. Each fuel assembly with their respective positions are predetermined arranged to form the reactor core. Due to the possibility of human errors, misposition of fuel assemblies might happen when operators load thoes fuel assemblies into the core. Therefore, it is necessary to investigate the effects of those misposition to the AP1000 neutronic parameters.

In this research, analysis of changes in the neutronic parameters of the AP100o core due to the mispositioning of two adjacent fuels was performed. Analyze is imposed to the core at hot zero power (HZP), beginning of cycle (BOC), and zero xenon condition. Neutronic 
parameters calculation was carried out by means of CITATION module of the Standard Reactor Analysis Code 2006 (SRAC2006) [12] computer code for $1 / 4$ core model in 2 dimension geometry. CITATION is a computer code, which uses diffusion theory in the multiplication factor calculation with finite different method to solve Boltzman equation. One of input data that is fuel macroscopic crossection was prepared using PIJ module. PIJ is a computer code based on transport theory with neutron collision probability method. The CITATION module of the SRAC2006 computer code has been validated for the criticality value of conventional PWR with good results [13]. From the analysis results, it is expected to know the safety characteristics of the AP1000 core's design.

\section{Methodology}

\section{Fuel Crossection Calculation}

The homogenization macroscopic crossection of the fuel calculation performed by PIJ module of the SRAC2006 through condensation 107 to 10 group of neutron energy. Cross section data library used in the calculation was JENDL-3.3. Input data required for those calculation is the size, dimensions and material that make up the fuel. Cross section calculations carried out on the $1 / 4$ part of the fuel lattice model in the two-dimentional geometry. Fuel lattice of the AP1000 core composed by $17 \times 17$ of fuel pin cell arrangement with water as moderator. Model of the fuel pin cell as showed at Figure 2. is composed from fuel pellets, gap, cladding and moderators in the square form with size of $1.25984 \mathrm{~cm} \times 1.25984 \mathrm{~cm}$. The outer part of pin cell is a moderator that consist a mixing of $\mathrm{H}_{2} \mathrm{O}$ and boron solution with concentration of 1382 ppm. There are two sort of fuel pellet, standard $\mathrm{UO}_{2}$ fuel and IFBA. Fuel pellets standard are $\mathrm{UO}_{2}\left(2,35 \mathrm{w} / 0,3,40 \mathrm{w} / \mathrm{o}\right.$ dan 4,50 w/0) and IFBA are $\mathrm{UO}_{2}$ fuel coated with $\mathrm{ZrB}_{2}$. Dimension of pellet, gap of the He gas and cladding of the ZIRLO are $r_{1}=0,409575 \mathrm{~cm}, r_{2}=0,426085 \mathrm{~cm}$, and $r_{3}=0,483235 \mathrm{~cm}$, respectively. Whereas IFBA fuel is same as standard fuel which $\mathrm{ZrB2}$ coated with amount of B-10 content of $0,772 \mathrm{mg} / \mathrm{cm}$. Composition of ZIRLO cladding are $\mathrm{Zr}$ $97,85 \%$, Fe 0,15\%, Sn 1,0 \%, dan Nb $1 \%$.

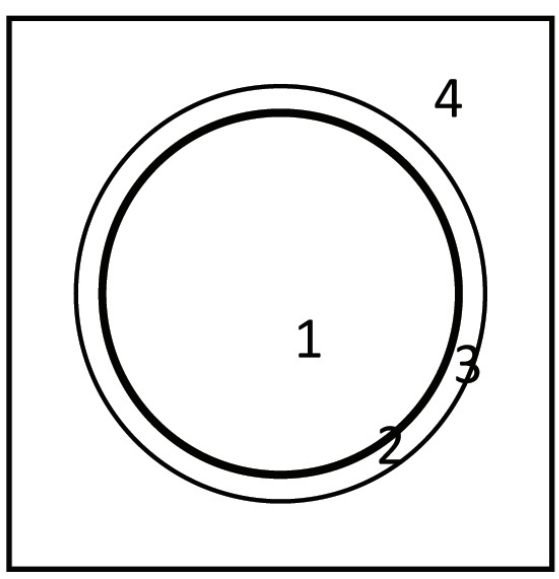

No.1=Fuel, No.2=Gap, No.3=Cladding, No.4=Modertor

Figure 2: Model of the fuel pin cell.

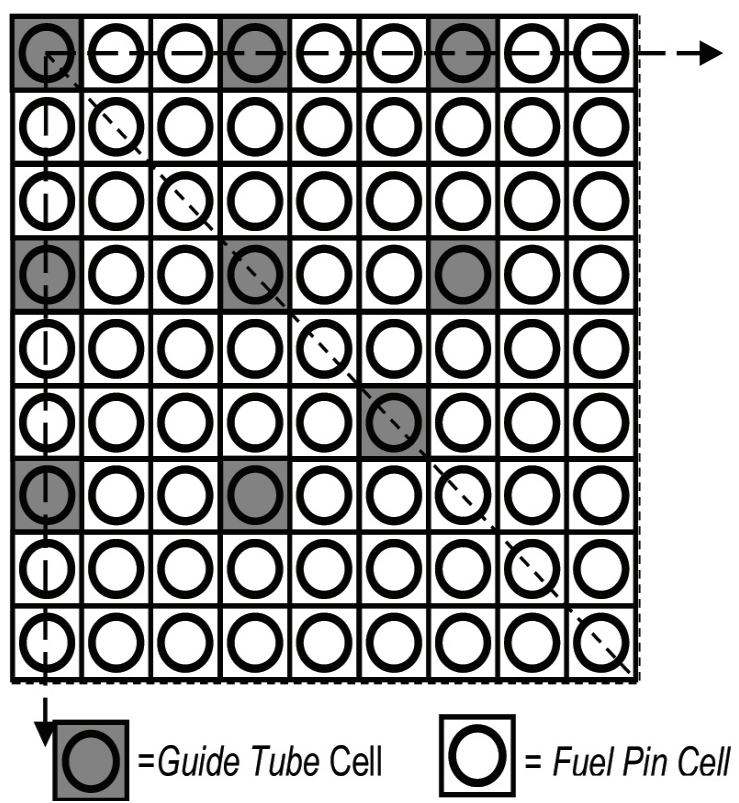

Figure 3: A Quarter geometry model of the fuel lattice. 
Figure 3 shows a quarter model geometry of the fuel lattice. Whole of the fuel lattice on the AP1000 core have size $21.50364 \mathrm{~cm} \times 21.50364 \mathrm{~cm}$ that contains 264 fuel, 25 guide tubes and with moderator $\mathrm{H}_{2} \mathrm{O}$. Guide tube is provided for absorber Pyrex, or Ag-In-Cd control rod, or moderator. Based on the amount of the fuel IFBA, then fuel lattice are divided into fuel lattice without IFBA, fuel lattice with 28 IFBA, 44 IFBA, 72 IFBA, 112 IFBA and 88 IFBA.

\section{Neutronic Parameters Calculation of the AP100 Core}

Neutronic parameters has been calculated for a quarter 2 dimensional geometry of AP1000 core. Input needed to core calculation using module CITATION of SRAC2006 are nuclide density of non fuel material, dimension size of the core, and homogenization macroscopic crossection of the fuel. Output from the core calculation using CITATION are k-eff, power distribution of the fuel, prompt neutron life time and generation time, as well as delayed neutron fraction.

As shown in Figure 4, two-dimentional model geometry of the AP100o core is built from fuel lattice of 3 type of fuel enrichment that are $2.35 \mathrm{w} / 0,3.40 \mathrm{w} / \mathrm{o}$ dan $4.50 \mathrm{w} / \mathrm{o}$ which relates to region number 1,2 and 3 respectively. Then, the core is surrounded by reactor baffle (no. 4), coolant (no. 5 and 7), reactor barrel (no. 6), reactor vessel (no. 8) and vacum (no. 9). Size and material composition of the core structure are reactor baffle from $\mathrm{SS}_{304}$, reactor barrel from SS304 with $d_{\text {in }} / d_{\text {out }} 339,725 \mathrm{~cm} / 349,885 \mathrm{~cm}$, reactor vessel from SS304 with $\mathrm{d}_{\text {in }} / \mathrm{d}_{\text {out }} 398,8$ $\mathrm{cm} / 420.1 \mathrm{~cm}$.

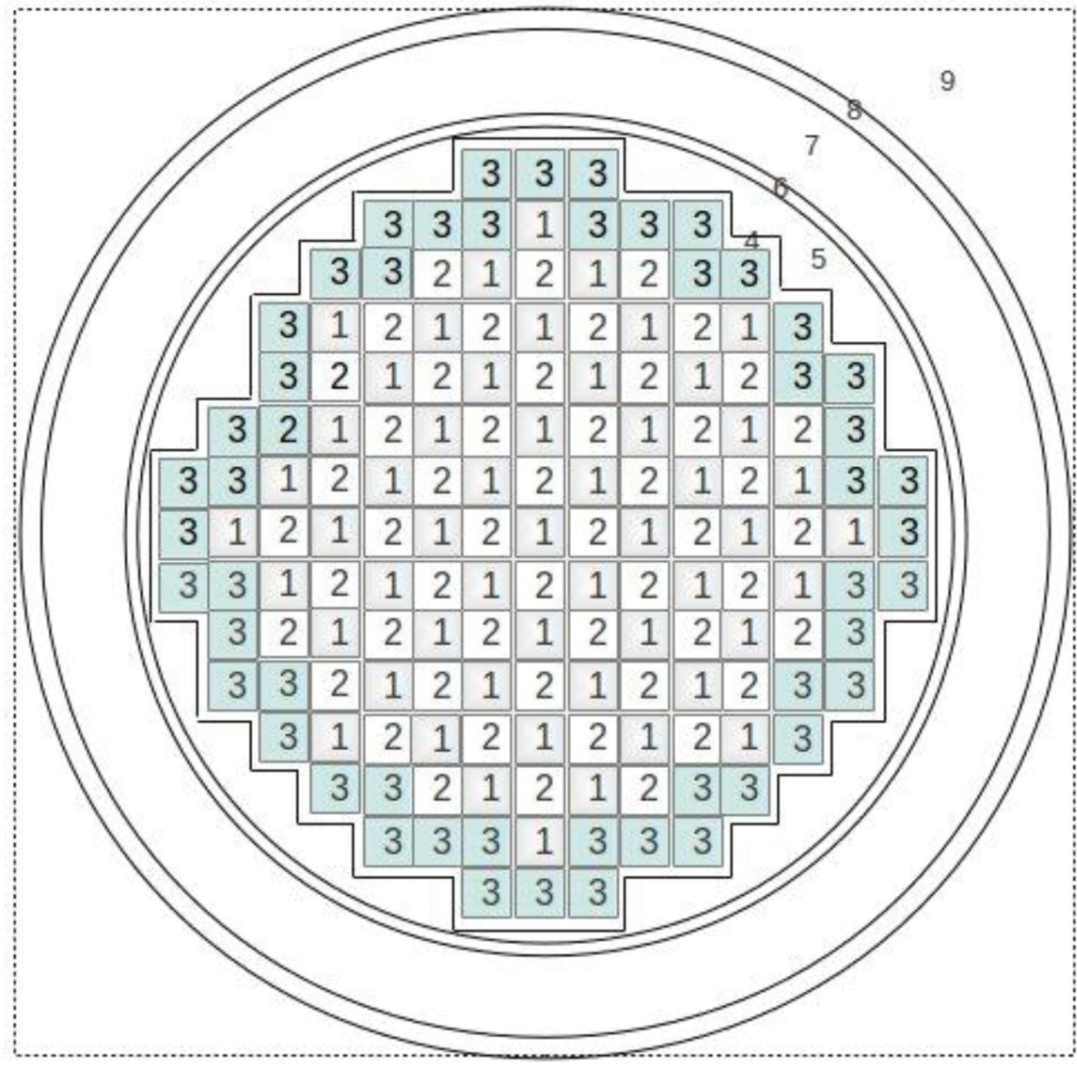

No.1,2, and $3=$ Fuel Lattice 1,2 and 3 , no. $4=$ baffle, no. $5=$ coolant, no. $6=$ barrel, no. $7=$ Coolant, no. $8=$ reactor vessel, no. $9=$ Vacum.

Figure 4: Radial core structure of the two-dimentional model AP1000 core. 


\section{Mispositioning of Two Adjacent Fuels Assumption}

In this study, analysis of the neutronic parameters change due to mispositioning of two adjacent fuel has been done. Such as illustrated in Figure 5., it is assumed that mispositioning have occur of two adjacentt fuel in the AP1000 core (Case 1 to 6). While the absorber rod Pyrex position was fixed, do not change from the design data. Case 1 to 6 are all located in column 8 start from the center to the edge of the core. Case 1 to 5 , the mispositioning accour between $\mathrm{UO}_{2} 3,40 \mathrm{w} / \mathrm{o} 24$ Pyrex 88 IFBA fuel with $\mathrm{UO}_{2} 2,3 \mathrm{w} / \mathrm{o}$ fuel. The mispositioning fuel in the core were $\mathrm{G}-8 \leftrightarrow \mathrm{F}-8, \mathrm{~F}-8 \leftrightarrow \mathrm{E}-8, \mathrm{E}-8 \leftrightarrow \mathrm{D}-8, \mathrm{D}-8 \leftrightarrow \mathrm{C}-8$ and $\mathrm{C}-8 \leftrightarrow \mathrm{B}-8$. Whereas, mispotition fuel in the case 6 was between $\mathrm{UO}_{2} 4,45 \mathrm{~W} / 012$ Pyrex 88 IFBA and $\mathrm{UO}_{2} 2,35 \mathrm{~W} / \mathrm{o}$ fuel.

\begin{tabular}{|c|c|c|c|c|c|c|c|c|}
\hline $\mathrm{H}$ & $G$ & $\mathrm{~F}$ & $E$ & $\mathrm{D}$ & C & B & A & \multirow[b]{2}{*}{ (Case $1: \mathrm{G}-8 \leftrightarrow \mathrm{F}-8$ ) } \\
\hline 2.35 & $2 4 \longdiv { P }$ & $\begin{array}{r}3.40 \\
881\end{array}$ & $\begin{array}{c}3.40 \\
881 \\
24 \mathrm{P}\end{array}$ & 2.35 & $\begin{array}{c}3.40 \\
281 \\
24 \mathrm{P}\end{array}$ & 2.35 & $\begin{array}{c}4.45 \\
881 \\
12 P\end{array}$ & \\
\hline $\mathrm{H}$ & G & $\mathrm{F}$ & $E$ & D & C & B & A & \\
\hline 2.35 & $\begin{array}{c}3.40 \\
881 \\
24 \mathrm{P}\end{array}$ & $\begin{array}{l}3.40 \\
881<\end{array}$ & $\begin{array}{l}\Rightarrow_{24 \mathrm{P}}^{2.35} \\
\end{array}$ & 2.35 & $\begin{array}{c}3.40 \\
281 \\
24 \mathrm{P}\end{array}$ & 2.35 & $\begin{array}{c}4.45 \\
881 \\
12 P\end{array}$ & (Case $2: F-8 \leftrightarrow E-8$ ) \\
\hline
\end{tabular}

\begin{tabular}{|c|c|c|c|c|c|c|c|c|}
\hline $\mathrm{H}$ & $G$ & $\mathrm{~F}$ & $E$ & $D$ & C & B & A & \\
\hline 2.35 & $\begin{array}{c}3.40 \\
881 \\
24 \mathrm{P}\end{array}$ & 2.35 & $\begin{array}{r}2.35 \\
245\end{array}$ & $\begin{array}{c}3.40 \\
881\end{array}$ & $\begin{array}{c}3.40 \\
28 \mathrm{I} \\
24 \mathrm{P}\end{array}$ & 2.35 & $\begin{array}{c}4.45 \\
881 \\
12 \mathrm{P}\end{array}$ & (Case $3: \mathrm{E}-8 \leftrightarrow \mathrm{D}-8)$ \\
\hline
\end{tabular}

\begin{tabular}{|c|c|c|c|c|c|c|c|c|}
\hline $\mathrm{H}$ & $G$ & $F$ & $E$ & $D$ & C & B & A & \\
\hline 2.35 & $\begin{array}{c}3.40 \\
24 \mathrm{P} \\
881\end{array}$ & 2.35 & $\begin{array}{c}3.40 \\
281 \\
24 \mathrm{P}\end{array}$ & $\begin{array}{l}3.40 \\
28 \mathrm{~K}\end{array}$ & $>_{24 \mathrm{P}}^{2.35}$ & 2.35 & $\begin{array}{c}4.45 \\
88 \mathrm{I} \\
12 \mathrm{P}\end{array}$ & (Case $4: D-8 \leftrightarrow C-8)$ \\
\hline
\end{tabular}

\begin{tabular}{|c|c|c|c|c|c|c|c|c|}
\hline $\mathrm{H}$ & G & $\mathrm{F}$ & $E$ & $\mathrm{D}$ & C & B & A & \\
\hline 2.35 & $\begin{array}{c}3.40 \\
881 \\
24 \mathrm{P}\end{array}$ & 2.35 & $\begin{array}{c}3.40 \\
281 \\
24 \mathrm{P}\end{array}$ & 2.35 & 2.35 & $\begin{array}{r}3.40 \\
281\end{array}$ & $\begin{array}{c}4.45 \\
881 \\
12 \mathrm{P}\end{array}$ & (Case $5:$ C-8↔B-8) \\
\hline
\end{tabular}

\begin{tabular}{|c|c|c|c|c|c|c|c|c|}
\hline $\mathrm{H}$ & $G$ & $F$ & $E$ & $D$ & C & B & A & \\
\hline 2.35 & $\begin{array}{r}3.40 \\
881 \\
24 \mathrm{P}\end{array}$ & 2.35 & $\begin{array}{r}3.40 \\
881 \\
24 \mathrm{P}\end{array}$ & 2.35 & $\begin{array}{c}3.40 \\
281 \\
24 \mathrm{P}\end{array}$ & 4.45 & $\begin{array}{r}2.35 \\
>_{12 \mathrm{P}}\end{array}$ & (Case $6: \mathrm{B}-8 \leftrightarrow \mathrm{A}-8$ ) \\
\hline
\end{tabular}

Figure 5: Misposition fuel located in column 8 of the quarter AP1000 core for case 1 to 6.

\section{Results And Discussions}

\section{Change in the Effective Multiplication Factor}

Calculation results of the $k_{\text {eff }}$ value changes due to the misposition fuel of AP100o core are shown in Table 1. The standard core that has same configuration of the fuel with design data showed that the value of $k_{\text {eff }}$ is 1,001910 . Whereas the value of $k_{\text {eff }}$ for the first operating cycle of the AP1000 core at Hot Full Power, BOC, Zero Xenon condition in the reference data is 1,00. 
Therefore, differences among calculation result with reference data is 0,001910 or $0,19 \%$. So that, it can be said that the keff value of AP100o core calculation result using module CITATION of the SRAC2006 computer code is about the same with refferences value.

TABLE 1: Change of the $k_{\text {eff }}$ value due to the mispositioning fuel in the AP1000 core.

\begin{tabular}{|c|c|c|c|c|}
\hline \multirow{2}{*}{ No } & \multirow{2}{*}{ Case of AP1000 Core } & \multirow{2}{*}{$k_{\text {eff }}$} & \multicolumn{2}{|c|}{ Change of the $k_{\text {eff }}$ value } \\
\hline & & & $\Delta k=k_{n}-k_{0}$ & $\%$ \\
\hline 1 & Standard Core $\left(k_{\mathrm{o}}\right)$ & 1.001910 & - & - \\
\hline 2 & Case $1\left(k_{1}\right)$ & 1.004707 & 0.002797 & 0.28 \\
\hline 3 & Case $2\left(k_{2}\right)$ & 1.004228 & 0.002318 & 0.23 \\
\hline 4 & Case $3\left(k_{3}\right)$ & 1.003691 & 0.001791 & 0.18 \\
\hline 5 & Case $4\left(k_{4}\right)$ & 1.003488 & 0.001578 & 0.16 \\
\hline 6 & Case $5\left(k_{5}\right)$ & 1.004056 & 0.002146 & 0.21 \\
\hline 7 & Case $6\left(k_{6}\right)$ & 1.001718 & -0.000192 & -0.02 \\
\hline
\end{tabular}

\begin{tabular}{|c|c|c|c|c|c|c|c|c|}
\hline \multirow{5}{*}{8} & $\mathrm{H}$ & G & $\mathrm{F}$ & $E$ & D & C & B & A \\
\hline & 1.279 & 1.154 & 1.268 & 1.137 & 1.254 & 1.161 & 0.957 & 0.541 \\
\hline & 1.192 & 1.081 & 1.198 & 1.097 & 1.246 & 1.198 & 1,006 & 0.580 \\
\hline & 0.049 & 0.026 & 0.042 & 0.018 & 0.037 & 0.038 & 0.069 & 0.020 \\
\hline & (3.81) & (2.28) & (335) & $(1.60)$ & $(2.92)$ & (3.31) & $(7.16)$ & (3.76) \\
\hline \multirow[t]{4}{*}{9} & 1.154 & 1.273 & 1.142 & 1.250 & 1.113 & 1.168 & 0.913 & 0.436 \\
\hline & 1.081 & 1.194 & 1.123 & 1.218 & 1.104 & 1.123 & 0.825 & 0.406 \\
\hline & 0.026 & 0.045 & 0019 & 0.032 & 0.009 & 0.045 & 0.088 & $0.030)$ \\
\hline & $(2.28)$ & (3.52) & (1.64) & $(2.60)$ & $(0.84)$ & $(3.84)$ & (9.63) & \\
\hline \multirow[t]{4}{*}{10} & 1.268 & 1.142 & 1.250 & 1.111 & 1.203 & 1.026 & 0.815 & \\
\hline & 1.226 & 1.123 & 1.221 & 1.114 & 1.204 & 1.033 & 0.798 & \\
\hline & 0.042 & 0.019 & 0.029 & -0.003 & -0.001 & -0.007 & $(0.017)$ & \\
\hline & (3.33) & (1.63) & $(2.35)$ & $(-0.26)$ & $(-0.07)$ & $(-0.65)$ & $(2.13)$ & \\
\hline \multirow[t]{4}{*}{11} & 1.137 & 1.250 & 1.111 & 1.193 & 1.033 & 1.041 & 0.561 & \\
\hline & 1.119 & 1.218 & 1.114 & 1.201 & 1.071 & 1.105 & 0.581 & \\
\hline & 0.018 & 0.032 & -0.003 & -0.008 & -0.038 & $-0,064$ & -0.020 & \\
\hline & $(1.55)$ & $(2.56)$ & $(-0.28)$ & $(-0.71)$ & $(-3.69)$ & $(-6,18)$ & -3.52 & \\
\hline \multirow[t]{4}{*}{12} & 1.254 & 1.113 & 1.203 & 1.033 & 0.859 & 0.630 & & \\
\hline & 1.218 & 1.104 & 1.205 & 1.071 & 0.888 & 0.680 & & \\
\hline & 0.036 & 0.009 & -0.002 & -0.038 & -0.029 & -0.050 & & \\
\hline & (2.83) & $(0.77)$ & $(-0.13)$ & $(-3.69)$ & -3.43 & $(-7.94)$ & & \\
\hline \multirow[t]{4}{*}{13} & 1.161 & 1.168 & 1.026 & 1.041 & 0.630 & & & \\
\hline & 1.124 & 1.125 & 1.034 & 1.106 & 0.680 & & & \\
\hline & 0.037 & 0.043 & -0.008 & $(-0.065)$ & -0.050 & & & \\
\hline & (3.15) & (3.72) & $(-0.78)$ & $(-6.25)$ & $(-7.98)$ & & & \\
\hline \multirow[t]{4}{*}{14} & 0.957 & 0.913 & 0.815 & 0.561 & & & & \\
\hline & 0.891 & 0.827 & 0.799 & 0.581 & & & & \\
\hline & 0.066 & 0.086 & 0.016 & -0.020 & & & & \\
\hline & (6.92) & 9.43 & $(1.98)$ & $(-3.62)$ & & & & \\
\hline \multirow[t]{4}{*}{15} & 0.541 & 0.436 & & & \multicolumn{4}{|c|}{ Reference Value (pref.) } \\
\hline & 0.524 & 0.408 & & & & Standarc & Core ( $\left.\mathrm{p}_{\text {std. }}\right)$ & \\
\hline & 0.017 & 0.028 & & & & Differenc & $\left(p_{\text {ref. }}-p_{\text {std. }}\right)$ & \\
\hline & (3.15) & (6.40) & & & & Differ & ces (\%) & \\
\hline
\end{tabular}

Figure 6: Comparison calculation result and refference value of power factor distribution of the $1 / 4 \mathrm{AP} 1000$ core at hot full power, BOC, zero xenon condition. 
From this table it can also be known that except case 6, mispositioning of the fuel in tne AP10o core cause a small increament in the value of $k_{\text {eff }}$. As it is known that in the case 1 to 5 mispositioning of fuel occured between $\mathrm{UO}_{2} 3.40 \mathrm{~W} / \mathrm{o} 88$ IFBA fuel with $\mathrm{UO}_{2} 2.35 \mathrm{~W} / \mathrm{O}$ fuel with each position are $\mathrm{F}-8 \leftrightarrow \mathrm{E}-8, \mathrm{E}-8 \leftrightarrow \mathrm{D}-8, \mathrm{D}-8 \leftrightarrow \mathrm{C}-8$ and $\mathrm{C}-8 \leftrightarrow \mathrm{B}-8$, repectively. It causes the location of 2 absorber Pyrex and IFBA are separated with different grid position. While in the initial design, 2 absorber Pyrex and IFBA located on the same grid position.

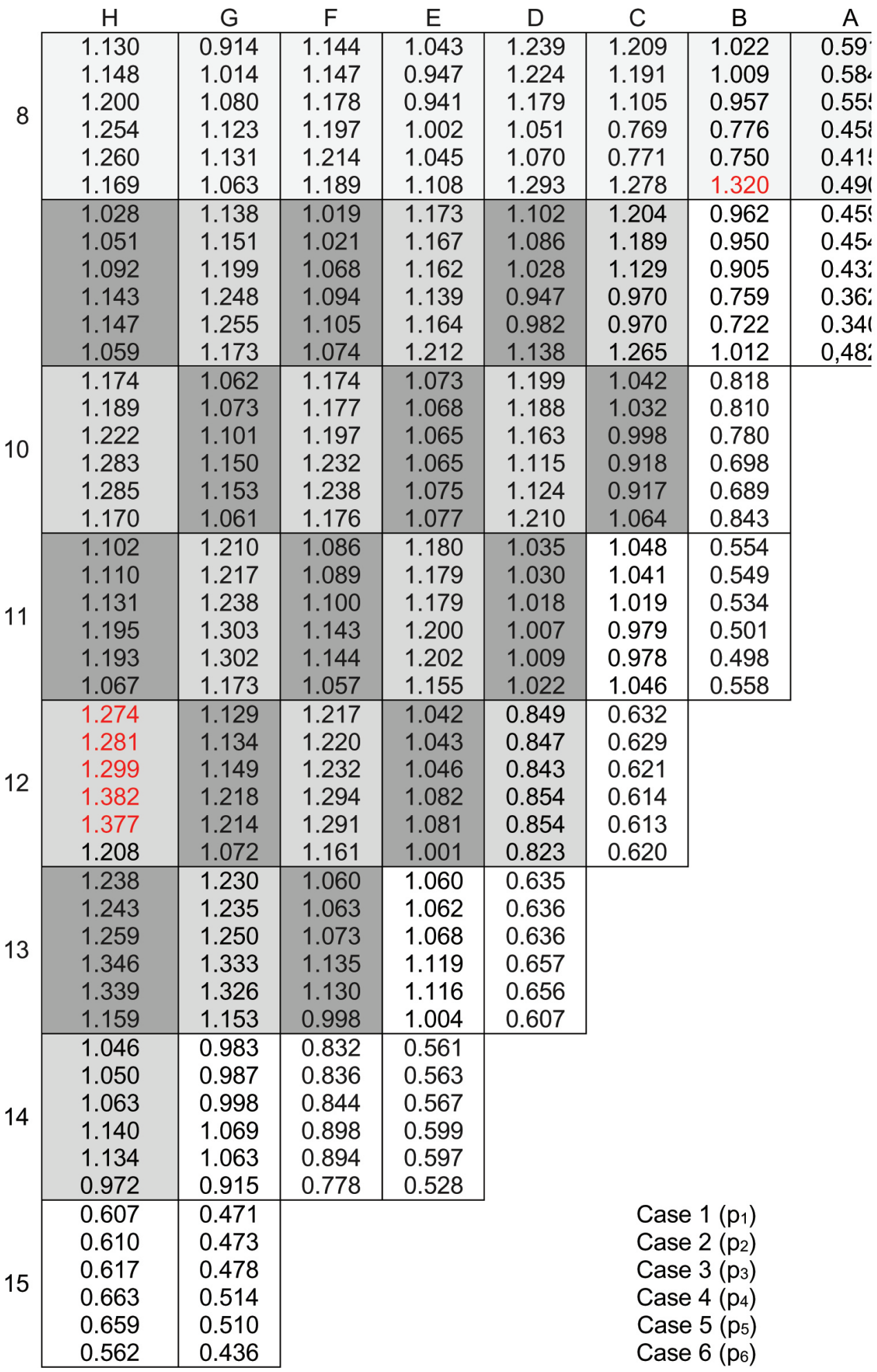

Figure 7: Power Factor Distribution in the $1 / 4$ AP10oo Core for Case 1 to 6 in Term of The Misspositioning Fuel at Hot Full Power, BOC, Zero Xenon Condition. 
Therefore, it would result in a decrease in thermal neutron absorption. Furthermore it will increase the value of thermal neutron utilization factor whichby, then, rising $k_{\text {eff }}$ value of the core. The biggest $k_{\text {eff }}$ value changes due to misposition fuel in the core is 0.002797 or approximately $0.28 \%$, that is for the case 1 ( $G-8 \leftrightarrow \mathrm{F}-8$ ). This is caused by the $\mathrm{UO}_{2}$ fuel with $2.35 \mathrm{w} / \mathrm{o}$ enrichment without absorbent material IFBA moved its position to the centre of the core. So due to the influence of the interaction of neutrons produced by the two fuel U02 $2.35 \mathrm{w} / \mathrm{O}$ in the centre of core resulting the increase of the neutron thermal utilization. While the case 6 , mispositioning of the fuel occurs in the outer position of the core. That are mispositioning among $\mathrm{UO}_{2} 2.35 \mathrm{~W} / 0$ fuel ( $\left.\mathrm{A}-8\right)$ with $\mathrm{UO}_{2} 4.5 \mathrm{~W} / 088 \mathrm{IFBA}$ fuel (B-8). In this case 6 , the keff value decreases about $-0.000192(-0.02 \%)$, which is from 1.001718 to 1.001910 . This is caused by the fuel with lowest enrichment ( $\left.\mathrm{UO}_{2} 2.35 \mathrm{w} / \mathrm{o}\right)$ in outer position of the core (A-8) which also contained 12 absorber rods Pyrex. Thereby decreasing neutron thermal utilization factor and it will also decreasing of the $k_{\text {eff }}$ value.

\section{Power Factor Distribution}

Figure 6 shows calculated power factor distribution at first cycle operation of the AP1000 at HFP, BOC, Zero Xenon conditions compared to the reference value. It shows that the maximum power factor from SRAC 2006 CITATION module calculation is 1.246 at position D-8. Whereas from the reference, its value is 1.279 and at position $\mathrm{H}-8$. The difference of theis maximum value is 0.033 or $2.58 \%$. At position $\mathrm{D}-8$, the reference value is 1.254 or $0.037(2.92 \%)$ difference. The maximum differences of the power factor values are occured at positions B-9 and G-14 which are amount to $0.088(9.63 \%)$ and 0.086 (9.43\%). The differences of the calculated and reference values can be resulted from the differences in the computer codes module and input data used by the reference.

Nevertheless, based on the power distribution, it can be said that the both results are in a good agreement. Fuel lattice with high power factor $\left(P_{i}>1,2\right)$ occurs at $\mathrm{UO}_{2}, 2.35 \mathrm{~W} / \mathrm{o}$ enrichment without absorber IFBA or Pyrex. On the other hand, fuel lattice with small power factor $(<0.6)$ occurs for $\mathrm{UO}_{2}, 4.45 \mathrm{~W} / \mathrm{o}$ enrichment. It is caused by its positions are in the outer part of the core that has lower neutron fluxes compared to that in the inner part. It can be concluded that the value of power factor depends besides on the enrichment also on the incore position and the existence of absorber in the fuel as well.

Calculation results of power factor distribution for $1 / 4$ core of the AP100o due to fuel mispositioning case 1 to 6 is presented in Figure 7. From the table it is found that maximum power factors for case 1 to 5 occurs in the same position that ic at $\mathrm{H}$-12. Those values are 1.274, $1.281,1.299,1.382$ and 1.377 consecutively. Thhese maximum power factor values still lays below the predetermined safety limit of 1.6. The figure shows also that mispositioning of fuel causes slightly changes in power factor distribution compared to initially designed.

\section{Prompt Neutron Parameter}

Calculation results of prompt neutron lifetime and prompt neutron generation time of AP1000 core due to fuel mispositioning are illustated in Table 2. The value of the standard core (20.7006 $\mu \mathrm{s})$ is slightly higher than the reference value $(19.8 \mu \mathrm{s})$ or about $4.5 \%$ difference. For all cases of fuel mispositioning (1-6), the maximum changes of prompt neutron lifetime and prompt neutron generation time are $2.35 \%$ and $2.06 \%$ that is for Case 1 . In other words, mispositioning of fuel does not give any significant changes for prompt neutron lifetime and prompt neutron generation time. 
TABLE 2: Change of prompt neutron lifetime $(/)$ and prompt neutron generation time $(\Lambda)$ core AP10oo due to fuel mispositioning.

\begin{tabular}{|c|c|c|c|c|c|c|}
\hline \multicolumn{4}{|c|}{$\begin{array}{l}\text { Prompt neutron lifetime, } \\
\qquad /(\mathrm{ms})\end{array}$} & \multicolumn{3}{|c|}{$\begin{array}{l}\text { Prompt neutron generation time, } \\
\qquad \wedge(\mathrm{ms})\end{array}$} \\
\hline AP1000 Core & Calculation & \multicolumn{2}{|c|}{ Difference (\%) } & Calculation & \multicolumn{2}{|c|}{ Difference (\%) } \\
\hline Standard core & 20.7006 & - & & 20.6611 & - & \\
\hline Case 1 & 21.1862 & 0.4856 & $2.35 \%$ & 21.0870 & 0.4259 & $2.06 \%$ \\
\hline Case 2 & 20.9238 & 0.2272 & $1.10 \%$ & 20.8357 & 0.1746 & $0.85 \%$ \\
\hline Case 3 & 21.0300 & 0.3294 & $1.59 \%$ & 20.9527 & 0.2916 & $1.41 \%$ \\
\hline Case 4 & 20.7698 & 0.0693 & $0.33 \%$ & 20.6976 & 0.0365 & $0.18 \%$ \\
\hline Case 5 & 20.9406 & 0.2400 & $1.16 \%$ & 20.8560 & 0.1949 & $0.94 \%$ \\
\hline Case 6 & 20.6070 & -0.0936 & $-0.45 \%$ & 20.5716 & -0.0895 & $0.43 \%$ \\
\hline
\end{tabular}

\section{Delayed Neutron Parameter}

Table 3 shows the comparison of calculation and reference value of the delayed neutron fraction $\left(B_{\text {eff }}\right.$ ) for all 6 cases of fuel mispositioning at AP 1000 core. The design or reference value is $7.5^{\times 10^{-3}}$, so deviation of calculation result is 0.5759 or $7.68 \%$. Then, it can be said that calculation of kinetics parameter using SRAC2006-CITATION give a good result.

It is also shown from the table that delayed neutron fraction $\left(B_{\text {eff }}\right)$ of AP1000 core a very small change either up or down with maximum change of $5.02 \times 10^{-6}$ or $0.073 \%$ for cases of fuel mispositioning.

TABLE 3: Change of delayed neutron fraction, $B_{\text {eff }}$ core AP100o due to fuel mispositioning.

\begin{tabular}{|c|c|c|c|}
\hline & \multicolumn{2}{|c|}{ Delayed neutron fraction, $B_{\text {eff }}$} \\
\hline AP1000 Core & Calculation & \multicolumn{2}{|c|}{ Difference (\%) } \\
\hline Standard core & $6.92410 \times 10^{-3}$ & -- & - \\
\hline Case 1 & $6.92046 \times 10^{-3}$ & $-3.64 \times 10^{-6}$ & $-0.050 \%$ \\
\hline Case 2 & $6.92592 \times 10^{-3}$ & $1.82 \times 10^{-6}$ & $0.026 \%$ \\
\hline Case 3 & $6.92028 \times 10^{-3}$ & $-3.82 \times 10^{-6}$ & $-0.055 \%$ \\
\hline Case 4 & $6.92912 \times 10^{-3}$ & $5.02 \times 10^{-6}$ & $0.073 \%$ \\
\hline Case 5 & $6.92391 \times 10^{-3}$ & $-1.90 \times 10^{-7}$ & $0.003 \%$ \\
\hline Case 6 & $6.92342 \times 10^{-3}$ & $-6.80 \times 10^{-7}$ & $0.010 \%$ \\
\hline
\end{tabular}

Reference value of delayed neutron fraction, $B_{\text {eff }}: 7.5^{\times} 10^{-3}$

\section{Conclusion}

Neutronic parameter analysis has been done due to the mispositioning of the fuel in the first operating cycle of the AP1000 at Hot Full Power, BOC, Zero Xenon condition. From the analysis, it can be concluded that misposition of the fuel in the AP1000 core insignificantly change the neutronic parameters, so it will not reduce the performance of the core.

\section{Acknowledgement}

Authors would like to say thank you to Prof. Drs. Surian Pinem, M.Si. for his priceless advice and also to the Head of the Nuclear Reactor Physic And Technology Division as well as the Director of the Center for Nuclear Reactor Technology and Safety for supporting this research. 


\section{References}

[1] Balendra Sutharshan, Meena Mutyala, Ronald P Vijuk and Alok Mishra, "Asian Nuclear Prospects 2010-The AP1000TM Reactor: Passive Safety and Modular Design-", Journal of Energy Procedia oo (2010) 000-0oo.

[2] W. E. Cummins, M.M. Corletti, T. L. Schulz, "Westinghouse AP10oo Advanced Passive Plant", Proceedings of ICAPP '03, Cordoba, Spain, May 4-7, 2003, Paper 3235

[3] Jati Susilo and Rokhmadi, "Analysis of Criticallity Parameter of AP100o Reactor Core Using SRAC-CITATION", Prosidings of Scientific Meeting and Presentation on Basic Research and of Nuclear Science and Technology, Yogyakarta, 24-25 September 2013, Pp. 94-102

[4] T. M. Sembiring and S. Pinem, "Evaluation of Moderator Temperature Coefficient of Reactivity for The 1000 MW PWR Nuclear Plant", Prosidings of National Seminar 17th Technology And Safety of NPP and Nuclear Facility, Yogyakarta, October 1st, 2011, pp.164-174

[5] Jati Susilo and Lily Suparlina, "Analysis of Kinetic Parameter As a Function of Burn up of the AP1000 Core", Prosidings of National Seminar 19th Technology And Safety of NPP and Nuclear Facility, Yogyakarta, September 24-25, 2013, pp.13-23

[6] Tagor Malem Sembiring and Surian Pinem, "Evaluasi of Delayed Neutron Parameter of AP1000 Reactor", Prosidings of National Seminar 18th Technology And Safety of NPP and Nuclear Facility, September 29, 2012, pp. 67-75

[7] Tukiran Surbakti, "Optimization of MOX Fuel for Core Design of AP10oo Reactor", Prosidings of National Seminar 19th Technology And Safety of NPP and Nuclear Facility, Yogyakarta, September 24-25, 2013, pp. 23-34

[8] Rokhmadi, "Analisys of Control Rod Reactivity on The PWR AP100o Design Fueled MOX", Prosidings of National Seminar 19th Technology And Safety of NPP and Nuclear Facility, Yogyakarta, September 24-25, 2013, Pp.34-45

[9] Tukiran Surbakti , "Evaluation of Kinetic Parameter for The Safety of The AP10oo Core Used MOX Fuel", Prosidings of National Seminar 2oth Technology And Safety of NPP and Nuclear Facility, Pontianak, June 19, 2014, pp.859-868

[10] Anonim, "AP1000 Design Control Document Chapter 4", from:http://www.nrc.gov/ reactors/new-reactors/design-cert/ap1000/dcd/Tier\%202/Chapter\%204/4-1_r14.pdf, January 20, 2012

[11] T. L. Schulz, "Westinghouse AP1000 advanced passive plant", Journal of Nuclear Engineering and Design 236 (2006), pp. 1547-1557.

[12] Keisuke Okumura, Teruhiko Kugo, Kunio Kaneko and Keichiro Tsuchihashi, "SRAC2006; A Comprehensive Neutronics Calculation Code System", JAERI-Data/Code 2007-004, Japan Atomic Energy Agency, January 2007

[13] Jati Susilo, "Verification of MVP-II and SRACo6 Code for the Case VERA Benchmark Reactor Core", Journal TDM Vol.16, No.2, June 2014, ISSN 1411-240X, No. Acreditation: 402/AU2/ P2MI-LIPI/04/2012, Pp.75-88 